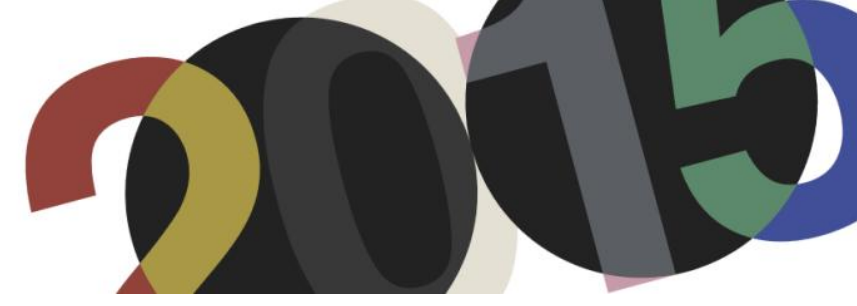

DOI: http://dx.doi.org/10.4995/LC2015.2015.921

\title{
Le Corbusier in Berlin, 1958: the universal and the individual in the unbuilt city
}

\author{
M. Oliveira Eskinazi \\ Faculdade de Arquitetura e Urbanismo, Universidade Federal do Rio de Janeiro. Programa de Pós-Graduação \\ em Urbanismo, Universidade Federal do Rio de Janeiro
}

\begin{abstract}
Among several urban plans designed for Berlin, we find Le Corbusier's project for the Hauptstadt Berlin 1958 competition, which aimed at thinking the reconstruction of the city center destroyed in the II World War. Corbusier's relation with Berlin dates back to 1910, when he arrives at the city to work at Peter Behrens`office. So, for him, the plan for Berlin was a rare opportunity to develop ideas about the city that provided one of the largest contributions to his urban design education, and also to develop ideas he formulated forty years before for Paris'center. Besides that, this project was developed almost simultaneously with CIAM`s crises and dissolution, which culminated in the 50`s with the consequent appearance of Team 10. At that moment Corbusier's universalist approach to urbanism starts to be challenged by CIAM's young generation, which had a critical approach towards the design methods inherited from the previous generation, associated with CIAM`s foundational moment. From the beginning of the 50's on, this new generation balances the universalist ideals inherited from the previous generation with individualist ones they identified as necessary to face the new post war reality. Thus, the main goal of this paper is to analyse Corbusier's design for Berlin and question whether he, at an already mature point of his career, was proposing a plan that answered only the questions that were important to CIAM and to the canonical principles of modern architecture, or if he had also addressed those that belonged to the new generation and Team 10 `s agenda, both of them present in the debates of the moment, largely identified as a transitional period.
\end{abstract}

Resumen: Entre varios planes urbanos diseñados para Berlín, esta el proyecto de Le Corbusier para el concurso Hauptstadt Berlín 1958, que tenia como objetivo pensar la reconstrucción del centro de la ciudad, destruida en la II Guerra Mundial. La relación de Corbusier con Berlín se remonta a 1910, cuando llega a la ciudad para trabajar en la oficina de Peter Behrens. Así que, para él, el plan de Berlín fue una rara oportunidad de desarrollar ideas sobre la ciudad que dio una de las mayores enseñanzas a su aprendizaje en diseño urbano, y también para desarrollar las ideas que formuló cuarenta años antes para el centro Paris. Además de eso, este proyecto se ha desarrollado simultáneamente con la crisis y disolución de CIAM, y con la aparición de Team 10. En ese momento, el enfoque universalista de Corbusier comienza a ser cuestionado por la generación joven de CIAM, que tenía enfoque crítico hacia los métodos de diseño heredados de la generación anterior. Desde el principio de los 50`s, esta nueva generación equilibra los ideales universalistas heredados de la generación anterior con los individualistas necesarios para hacer frente a la nueva realidad. Por lo tanto, lo principal objetivo de este trabajo es analizar el diseño de Corbusier para Berlín y cuestionar si, en un punto ya maduro de su carrera, él propone un plan que respondió sólo las cuestiones que eran importantes para CIAM y a los principios canónicos de la arquitectura moderna, o si también se trataron temas que pertenecían a la nueva generación y a la agenda del Team 10, ambos presentes en los debates del momento, en gran parte identificado como un período de transición.

Keywords: Berlin; competition; reconstruction; universal; individual; transitional period.

Palabras clave: Berlín; concurso; reconstrucción; universal; individual; periodo de transición.

\section{Le Corbusier in Berlin}

One among several urban plans designed for Berlin that were never built is Le Corbusier`s project for the Hauptstadt Berlin 1958 competition, which also received projects from Alison and Peter Smithson, Hans Scharoun and others, and aimed at thinking the reconstruction of the city center destroyed in the II World War. But for Le Corbusier it was also a rare opportunity to develop ideas he formulated forty years before for Paris` center. 
Le Corbusier`s relationship with Berlin dates back almost fifty years, when in October 1910 he arrives at the city and starts working at Peter Behrens`office. Nevertheless, his first impression of the city was not a good one, as can be inferred from letters he wrote to his parents:

\author{
"Berlin extended a horrid welcome to me this morning." 1 \\ "Berlin does not win me over, and once you leave the vast avenues, it is just revulsion, pure horror." ${ }^{2}$
}

However, this first impression slowly changes when Le Corbusier gets in touch with the large green areas of the city, both in the Berlins downtown and its suburbs, in future letters to his parents:

"In the Tiergarten, one enjoys anew the impression of great peace in this great forest in immediate proximity to the noisy roads." 3

"So that, when on a spring or summer evening, one takes a walk in any of these suburbs, the visitor arriving from the great furnace of Berlin will be deeply surprised; he will indeed feel himself living in a reviving peace."

But more important to establish his previous relationship with Berlin is the fact that the city provided one of the largest contributions to his urban design education. That happened because in this period he had the opportunity to visit several exhibitions, as the relevant Städtebau-Ausstellung, and participate in sessions of the Werkbund. Besides that, he got in touch with the winning proposals for the Gross-Berlin competition, which aimed at thinking and planning the urban development of the city. So, both the experience of living in Berlin and working at Behrens`office, together with attending exhibitions and sessions of Werkbund`s congress, strengthened the basis of his urban design thinking, in particular his understanding of the perception and modulation of urban space, and consequently in his way of articulating the space in architecture.

Other than that, his project for Berlin was developed almost simultaneously with CIAM`s crises and dissolution, which culminated in the 50`s with the consequent appearance of Team 10. At that moment the design methods associated with CIAM are being questioned. Besides that, Corbusier`s universalist approach to urbanism, which he championed in his Athens Charter, starts to be challenged by CIAM`s young generation, which included the Smithsons, van Eyck, Bakema and Candillis. This generation had a critical approach towards the design methods inherited from the previous one, which was associated with CIAM`s foundational moment, and had among its members, other than Le Corbusier, also Giedion, Gropius and Sert.

Regarding Corbusier`s universalist approach, from the beginning of the 50`s on, this new generation balances the universalist ideals inherited from the previous generation with individualist ones they identified as necessary to face the new post war reality. This group acts towards a way of thinking the city, which prioritizes aspects such as considering the individuality and specific features of the site, including the greatest spatial and social varieties in design, and the development of transitional elements of scale in the configuration of the architectural and urban space. That means that, at the same time that they pay tribute to the previous generation, they question a series of aspects of their contributions. These discussions were fought with greater intensity at CIAM 9, 1953, and CIAM 10, 1956.

\footnotetext{
${ }^{1}$ Jeanneret, letter to his parents, October 18th, 1910, FLC R1-5-67. In: Cohen, Jean-Louis. Le Corbusier: An Atlas of Modern Landscapes. New York: Thames \& Hudson, 2013, pp. 88.

${ }^{2}$ Jeanneret, letter to his parents, October 21st, 1910, FLC R1-5-68. In: Cohen, 2013, op. cit., pp. 88.

${ }^{3}$ Le Corbusier. Les Voyages d'Allemagne, sketchbook 2, pp. 122. In: Cohen, 2013, op. cit., pp. 89.

${ }^{4}$ Jeanneret, Étude sur le mouvement d'art décorativ en Allemagne, p. 48. In: Cohen, 2013, op. cit., pp. 89.
} 
Thus, taking into account both Le Corbusier`s relation to Berlin and his fundamental role in the debates held during CIAM`s congresses, this paper analysis his design for Hauptstadt Berlin 1958 competition. Even though his design was eliminated from the competition, it contains several interesting proposals, such as solutions for the traffic problems, transference of Hauptbahnhof to Friedrichstrasse`s station, transformation of Unter den Linden into a pedestrian promenade, insertion of a grid of eroded blocks around Friedrichstrasse, and the insertion of huge towers near the limits of the intervention area.

Therefore, this paper`s main goal with the analysis of Corbusier design for Berlin is to question whether he, at an already mature point of his career, was proposing a plan that answered only the questions that were important to CIAM and to the canonical principles of modern architecture and urbanism, or if he had also addressed those that belonged to the new generation and Team 10`s agenda, both of them present in the debates of the moment, largely identified as a transitional period.

\section{Le Corbusier and the 50s`agenda}

\subsection{The universal and the individual}

After the end of World War II, relevant theoretical discussions took place. Despite the fact that some of them were never tried out in the practice, they were decisive for architecture and urbanism developments that occurred in the following years. The anxieties and uneasiness that the post-WWII environment provoked to the modern architecture were increasingly debated, especially in the 50`s. From these debates raised an idea of city that paradoxically, at the same time, incorporated and criticized the heritage left by the modern vanguards. A dominant feature of the period between the end of WWII and the beginning of the 60`s, this paradox finds a parallel in the duality of the relationship between the concepts of universal and individual. It is therefore correct to say that the concept of universal is linked to the appropriation of the principals inherited from the modern vanguards and the individual one to its questioning. However, according to Annie Pedret, the concepts of universal and individual were confronted by the third generation of architects in a more subtle way than it is usually depicted, that is, with simplifications and generalizations. That means that, in order to understand an important feature of the changes occurred inside architecture in this period, these concepts require, first of all, to be understood not as opposing ones but as complimentary ones:

“(...) histories of postwar CIAM that do not take a critical view of rhetorical techniques - whether they exist in published statements or even in unpublished official reports and congress minutes - do not accurately represent a comprehensive reflection of historical reality. Team 10 members no longer found it possible to perceive of reality in oppositional terms, thus they replaced the notion of the individual versus the universal with the individual and the universal. This paradigm of duality provided the theoretical basis for the architecture of the 1960 s and added a level of complexity to its characterization from an "either/or" paradigm, to one that accepted "both/and." Writing histories is linked to who the writers are and what agendas they are trying to promote which requires that we, as historians, examine the larger more complex discourse underlying the accepted discourse." 5

Our approach to Le Corbusier`s 1958 project for Berlin is based on this understanding of how a dialect relationship between the concepts of universal and individual is dealt along the 50`s. This allow us to assume

\footnotetext{
${ }^{5}$ Pedret, Annie: Representing history or describing historical reality?: the universal and the individual in the 1950. Conference: Universal vs. Individual: The Architecture of the 1960. Chicago: Illinois Institute of Technology, 2002, pp. 4.
} 
that, despite the fact that Le Corbusier belonged to the first generation ${ }^{6}$ of modern architects and that he defended in several post-WWII CIAM`s congresses a more universalist approach in the same line as in the Athena's Chart, he was sensitive to the issues that were being addressed by the new generation and Team 10`s agenda, especially if we take in account his presence in the debates of the period. Therefore, it is possible to better assess Berlin`s project in the context of a transitional period. Therefore, this investigation evolved along the ideas of the complementarity of the concepts of universal an individual, the role of CIAM in the postwar and its influence in Le Corbusier`s proposal to the urban development of Berlin`s downtown.

Even before the end of the WWII, there are series of doubts and critics to the planning and project methods used by architects associated with the CIAM. However, this movement increases with CIAM`s first congress after the referred war, CIAM 6, which occurred in Bridgewater, England, 1947, when the group was challenged by a different reality than the one that existed before the war. From then one and throughout the next decade - with impressive strength on the second half of the 50`s - the more universalist approach to urbanism defended by Le Corbusier in the Athena's Chart starts to be challenged by a young generation at CIAM, which criticized the planning and project methods inherited from the previous generation, who were still very attached to the foundation of CIAM.

The more prominent members of this new generation were until 1954 called "young members", but after September 1954 they start to be known as Team 10. These "young members" balanced the universalist ideals inherited by the previous generation with those of individuality which they identified as necessary to face the new reality. Their intervention in the city was directed towards individuality and particular features without nevertheless abandoning completely the universalist ideals, as expressed in the Doorn Manifest of $1954 .^{7}$

This proposal of the new generation, defended by names like Alison and Peter Smithson, Aldo van Eyck, Jacob Bakema, Georges Candillis and John Woelcker, valuing aspects of individuality and the specific characteristics of each place and community, is commonly presented as a opposition to the observations made by the old one, represented by Le Corbusier, Siegfried Giedion, Walter Gropius and Josep Luis Sert, usually linked to more universal ideas. However, the young architects neither placed themselves against the functionalist city designed by the Athens Charter by explicitly questioning its universality. They expressed their disagreement indirectly proposing an alternative method of design that takes into account differences in several orders between things and people - these are social, cultural, historical, geographical, climatic or ethnic differences. And this posture can be verified in the search for a greater variety of typologies and a wider variety of open spaces, creating areas of different features and combinations both spatial and morphological, as social. These design strategies have enabled the modern architecture and urbanism of the 50s to expressing higher degrees of particularity and identity that approach a less universal understanding and therefore more emphasis on features that emphasize individuality.

Among the examples, the most explicit approach to these concepts of individuality and identity was performed by the Smithsons in the projects submitted by them in CIAM 10, $1956 .{ }^{8}$ Each project proposed a different dwelling type for a specific necessity, and so each dwelling should satisfy to individual needs and, at the same

\footnotetext{
${ }^{6}$ Montaner, Josep Maria: Depois do Movimento Moderno. Arquitetura da segunda metade do século XX. Barcelona: Gustavo Gili, 2001.

${ }^{7}$ Smithson, Peter and others: Doorn Manifest. CIAM meeting on 29, 30 and 31 de January, 1954. In: Smithson, Alison: Team 10 Primer. Boston: MIT Press, 1968, pp. 30.

${ }^{8}$ Smithson, Alison: The Emergence of Team 10 out of CIAM: Documents. London: Architectural Association, 1982, pp. 69.
} 
time, respect individual identities, but always starting from common organizational principles. Also Bakemapresents an approach that emphasizes identity-related demands of a time when the individuality of each resident should be considered. The projects developed by him together with Opbouw group to dwell areas in the Netherlands - such as Pendrecht, Alexanderpolder and Nagele, all presented in different editions of the CIAM congress of the 50's - addressed the creation of identity through different approaches to a scheme consisting of formations of housing units that, when grouped, make up the neighborhood units. The housing units of Bakema, as we shall see, resonate in the area south of Unter den Linden in Corbusier`s project for Berlin.

These examples show that architects that belonged to the new generation have done, over the 1950s, important practical trials, based on manifestos, studies and theoretical discourses at the same time valuing features of an individualistic nature, but also challenging the universalist beliefs of CIAM. However, other than the main narratives usually place, they did not abandon one for the other, but dedicated to the task of putting the two ideas relating to and dialoguing with each other. This means that to understand the ideas of modern city designed in the 50s considering all its nuances and complexity, the problem of the universal and the individual must be characterized in less superficial terms, showing the varied aspects that contributed to its development and consolidation.

In the context of this transition period, Le Corbusier, even standing as one of the main representatives of the previous generation, continues to have a significant role, which is also concomitant with the performance of the members of Team 10 and the so called new generation of modern architects. He still defended in the last congresses of CIAM that he participated a point of view that can be theoretically traced back to a more universalist position, that means linked with modern pioneers and the canonical principles of modern architecture, especially with zoning the city into four functions. This position is explained in a series of actions, such as the first session of CIAM 7, chaired by Le Corbusier, who expounded on "Applications of the Athens Charter"; the presentation of works at CIAM 7 stipulated by Corbusier in the form of a grid of CIAM, that is $21 \mathrm{~cm} \times 33 \mathrm{~cm}$ panels forming a grid which was a system to graphically organize information on the projects, so that they could be analyzed comparatively according to the categories set out in the Athens Charter; and his insistence in successive congresses of the postwar CIAM, in the preparation of the Habitat Charter, which would be a continuation of the Athens Charter, among others.

But what this paper aims to show, based on the analysis of the 1958 project for the reconstruction of central Berlin, is that, despite his public defense in theory and in the debates in the congress of the review and continuity of the design principles of the first generation, in practice the project to Berlin begins to demonstrate some solutions that combine universal aspects with individual ones that therefore are consistent with the discussions that have marked this period of transition. Among other solutions, as we shall see, in the Berlin project Corbusier demonstrates a concern with the lack of identity and differentiation of dwelling projects built in previous decades through the creation of buildings with unique shapes composed of irregular volumes, inserting a wide range of building types and configuration of blocks, and the creation of groups of linear buildings based on the idea of combining mirrored structures, forming various open spaces and graduating public and private spaces. Thus, it distinguishes between the different areas, strengthening the individuality of each area and its users. In the same sense is Le Corbusier's approach to open spaces, seeking the coexistence of open spaces with different scales, characters and relationships hierarchy, and with the presence of transitional elements between the public and private domains. 


\subsection{Le Corbusier's role in the CIAMs meetings of the second postwar}

As discussed above, the post-war witnessed a change in discourse and practice within CIAM. To comply with the new society that was born with the end of war, CIAM could no longer guide their progress values and improvements in the human environment by concepts based on rationalist and mechanistic assumptions. This search for a new route - not focusing merely on the functional and rational aspects of architecture and urbanism guided the debates of the period. In this chapter, it will be seen how Le Corbusier standed in this debate inside the CIAM congresses, in order to better understand the influence of his ideas on developing his project to Berlin, which occurred a few years after CIAM 9, when he was removed from the organization of conferences.

The postwar congresses were devoted to issues primarily related to the reconstruction of the cities, covering questions about how to humanize the process of industrialization, as well as the concepts of "core" and "Habitat". The leadership behind this discussion underwent through some changes in the process. From CIAM 9 on, the leadership was transferred from Le Corbusier and Giedion to an international circle of young architects who would form the Team 10. The CIAM 9 was the first moment in the history of this congress that the functional city is put into check; this was also the congress that witnessed closely the changes inside the CIAM.

Between the first two congresses held after World War II - CIAM 6 and 7 - none of them was able to produce consensus about new directions that CIAM should follow from now on in order to maintain its leading position in Europe. CIAM 6, held in Bridgwater, England, in September 1947, was marked by controversial discussions. A major issue was the position of Giedion and Le Corbusier as the main CIAM figures advocating the use of the Charter of Athens, which proposed the "Functional City" as the main purpose of CIAM. By that time, young architects began to challenge the position of the leaders, considering the Charter very "rigid" and "rationalist".

In CIAM 7, held in Bergamo, Italy, in July 1949, it was already clear that the event would not recover the vanguard status that it held before WWII, among other reasons due to conflicts within the organization. The discussions held during the conference showed that the overall focus seemed to be an extension of the ideas of Le Corbusier, who actively participated in the congress. The format itself of the works presented was established by Le Corbusier. He proposed that the projects submitted to CIAM should be on a grid format, in $21 \mathrm{~cm} \times 33 \mathrm{~cm}$ panels forming a grid which was a system to graphically organize information on the projects, so that they could also be analyzed comparatively according with the categories set out in the Charter of Athens. Thus, the CIAM grid started to be used as a matrix, presenting as column headings of the four functions of the Charter - dwelling, work, recreation, and transportation; in the lines of the grid themes were included such as context, volume built, ethical, aesthetic, economic and social impacts, financial, law, among others. According to Le Corbusier, the grid formed by the intersection of these two axes provides a tool for understanding and compare, with a visual method, the different projects. However, despite the fact that the grid proved to be an efficient method to organize project information and was therefore used until CIAM`s dissolution in 1956, there was significant opposition to it. Because it categorized the projects in a limited number of horizontal and vertical lines, it did not represents adequately the conditions in which it was working. This is because, due to its universalist and exclusivist character, the grid predisposed architects to think the city framed in terms of the four functions and preconceived static categories, as opposed to other factors that should be included or at least considered.

In addition, Corbusier advocated that CIAM 7 should have among its objectives the development of the Habitat Charter. The issue eventually continued to draw CIAM`s attention until 1956. The first plenary session held at CIAM 7, chaired by Le Corbusier, dealt with the subject "Charter Athens Applications", and in his introductory speech, Le Corbusier said CIAM should develop a Charter of Habitat for CIAM 7, without stating clearly what 
such Charter might contain 9

For the next congress, CIAM 8, held in 1951, Hoddesdon, north London, the title "The Heart of the City" was chosen and this subject reflects a concern of the organizers with interventions in the centers of cities. The theme was relevant especially for the reconstruction of bombed towns - as Berlin after the war. But at that moment it was already evident that the continued application by CIAM of the principles of Athena`s Charter, as desired by Corbusier, was not unanimous, and that was the key issue in the next Congress. The four functions set out in the Charter had initially proved useful for a first analysis of a city, but now were insufficient to capture all its complexity.

The Charter of Habitat, that Le Corbusier wanted to make already in CIAM 7, ended up not being produced. Other than that, the congress showed that, despite that the atmosphere in the postwar was favorable for the development of modern architecture and urbanism, as could be seen in the reconstruction projects being proposed everywhere, the old school of CIAM showed no signs that they would be able to assess realistically the complexities involved with the difficult urban situation resulting from postwar. Thus, in general, the CIAM was unable to regain its leading role in Europe in the first six years after the war. This allowed new generations of architects to claim the Congresses leadership already for the next one, CIAM 9. In a meeting with members of the council held still during the CIAM 8, was suggested by Corbusier that "the occasion of the next Congress would be a good opportunity to 'hand over ' to the younger members" ${ }^{10}$ since 1953 would be the 25 th anniversary of CIAM. The 'hand over' to the new generation represented the official start of efforts to revitalize CIAM, an effort that resulted in the formation of Team 10 after CIAM 9.

With Le Corbusier`s retiring from Congress organization, CIAM 9, held July 1953 in Aix-de-Provence, France, is organized by the old school of CIAM and the French group ASCORAL. The meeting is considered the largest and most diverse CIAM ever. Convened under the title "The Charter of Habitat," the congress was attended by over 3,000 participants, including van Eyck, Bakema, Alison and Peter Smithson, Candilis and Woods - mostly names that would soon become the Team 10 members.

CIAM 9 came, therefore, in order to try to place CIAM relevant again, approaching the reality through the incorporation of ideas that come from a younger generation. However, the connection between the old and the new generation and their ideas did not yield very spontaneously and smoothly. This difficulty was reinforced by the reluctance of the previous generation to include more young people in decisions regarding the future of CIAM, making it clear that the differences between them with regard to ways of thinking the city only increased and favored a sense of division within CIAM. This change of direction was enhanced by Le Corbusier`s doubt on the applicability of the initial ideas of the CIAM in the new postwar scenario. In a letter to Sert, Tyrwhitt writes:

"Corbu said also in the Council meeting that he no longer felt we could be confident about the way men should live in this changing world. He no longer felt he knew what 'a town' should be. The 'Habitat' is clearly an element of living space - Cobu is not sure 'urbanisme' is the correct word - but how it should be organized with the other elements is less and less clear. ${ }^{\prime \prime l}$

\footnotetext{
${ }^{9}$ Mumford, Eric: The CIAM discourse on urbanism, 1928-1960. Cambridge, Massachussets: Mit Press, 2002, pp. 192.

${ }^{10}$ Mumford, 2002, op. cit., pp. 206.

${ }^{11}$ Mumford, 2002, op. cit., pp. 218.
} 
That is, it was clear to Le Corbusier that, at that moment, the battle of modern architecture to give appropriate responses to architectural and urban problems of the reconstruction period could no longer be engaged on the same basis that worked before WWII. Therefore, the 1953 meeting was characterized by a common desire to both generations, but derived mainly from Le Corbusier and his group, to try once again to produce a Charter of Habitat, a document that, drawn up following 1933 Athens Charter, would provide a continuity to the production of manifestos and should be understood as a letter providing guidance and principles for the development of urbanism since then - as did the Charter of Athens in the pre-war period - and for the production of modern living spaces, one of the four specific functions of the Charter of Athens. However, once again the letter was not formulated.

The young architects, who would soon become members of Team 10, did not like the idea of producing another manifesto. It is without question that they paid tribute to the ideas associated with the Athens Charter, recognizing its value to restore the principles of order in the cities. On the other hand, they challenged the understanding that the organization could go on for another Charter from that same point. For them its principles were now considered inadequate since very abstract and diagrammatic. For this group, it was no longer possible to conceive the "town" and the living spaces from the mono-functional zoning perspective proposed by the Charter of Athens. In contrast, for the young architects, the "town" should henceforth be considered on the basis of human associations, as an attempt to correct the problem of human relations generated by the functional separation proposed in 1933. So it is no surprise that the work program of CIAM 9 points out that the Congress would not be reduced to the study of the four functions, but will focus on housing and everything that revolves around the planning and construction of dwelling.

As in CIAM 7, the studies in CIAM 9 were presented in form of grids $(21 \mathrm{~cm} \times 33 \mathrm{~cm}$ panels $)$, colored by function, and should contain a vertical line at the right edge $(6 \mathrm{~cm})$ containing title, location and author identification, numbering and a brief explanation. A total of forty grids were presented at CIAM 9. Among these, several projects aroused the interest of the younger members, especially those that showed some concern for local conditions and cultural traditions. CIAM 9 was considered the most internationalized and also the most diverse of the congresses so far conducted.

This makes it clear that it was precisely during the CIAM 9 that the generation of young architects starts to have an active participation and criticize, from different approaches, the schematic of the Charter of Athens, suggesting that, to address the issue of Habitat, it would be necessary to adopt a number of new positions such as the introduction of the concept of identity and the investigation of some structural principles of urban growth. And Le Corbusier, although remaining tied with respect to some aspects of the Charter, on the other hand was already showing signs that he understood that this was a period of transition and change paradigms.

Thus, CIAM 9 ends without having succeeded in producing a Charter of Habitat. Moreover, the discussions carried out have led to a split between the new generation and the old school, represented mainly by the figure of Le Corbusier, and that resulted, a few years later, in CIAM '59 and dissolution of CIAM. In the period that followed after the end of CIAM 9, criticism indicating the failure of Congress abounded among the members of the new generation, and began to be directed to CIAM as an institution. So CIAM 9 represents the turning point when CIAM's speech on the functional city, and with it, the validity of the Charter of Athens, were held in check and questioned openly by young architects. And it is from this perspective, claiming the revision of a number of canonical principles of modern architecture through the dwelling, that CIAM 9 plays a key role in understanding the ideas of review and continuity that characterize the theoretical framework where this investigation is made. 


\section{Berlin Hauptstadt 1958, the unbuilt city}

It is in the context of the debates presented above, and in the context of a divided Germany a few years before the effective construction of the Berlin wall in 1961, that Le Corbusier, a few years after attending for the last time a meeting of CIAM, submits his project for Berlin Hauptstadt 1958 contest. The competition solicited proposals for the reconstruction of Berlin`s historic downtown, that was largely destroyed by war. This same period also held other important initiatives of reconstruction of parts of the city destroyed by WW II, both in West and East Berlin. Among the most important, it is worth mentioning the Kollektivplan of 1945, first plan for the reconstruction of Berlin, designed by Hans Scharoun, but not built; among the built ones, are the Stalinallee 1951 in East Berlin, and the Interbau 1957 in West.

Announced immediately after the division of Germanys in 1949, the Stalinallee, today Karl-Marx-Allee, promoted the reconstruction of the Frankfurter Strasse between Strausberger Platz und Frankfurter Tor, and has been object of a competition in 1951. The definite plan puts together ideas of the five prizewinners and of Hermann Henselmann. Following the criteria of socialist realism current at the time of the German Democratic Republic constitution till the end of the 60's, the eclectic-academic architecture will triumph in the 1800m long and $80 \mathrm{~m}$ wide avenue. Details evoking Schinkel and its contemporaneous expressed the national character.

The Interbau, example of the best modern architecture and urbanism offered in terms of social housing, promoted the reconstruction of the Hansaviertel, a residential neighborhood from the eighteenth century located in the Tiergarten park. The urban plan was defined by a competition held in 1955, and the exhibition inaugurates in July 1957, with the participation of more than 40 architects. The list of invited includes Le Corbusier, with one Unité d'Habitation, and also Alvar Aalto, Walter Gropius, van den Broek and Bakema, Arne Jacobsen, Oscar Niemeyer, among others. While the monumentality of Stalinallee represented the triumph of socialism in East Germany, the new Hansaviertel would be a replica of the free and democratic society of the West.

On the other hand, the Berlin Hauptstadt 1958 competition was organized even closer to the materialization of the Berlin Wall - only three years before. The competition was planned in October 1955 by the West Berlin government, announced in May 1957, and have received proposals until February 1958. Thus, it stood as a unique opportunity to check the status and then the ideas about the city and its planning.

The notice requested solutions fort the administrative, financial and commercial centers of the city. It gave as a main guideline that the projects should address a future and hypothetical reunified Berlin. The crux of the matter was to think a new urban setting that would allow the future city to be related to the existing city and its vestiges. The program called for the design of a great political and administrative center for the reunified capital, with government offices, ministerial blocks around the Reichstag and a large public area with services, shops and offices; residential areas were excluded from the program - which would represent, if the winning project had been built, a great loss to Berlin`s downtown, which would be configured as an empty area at night and without the mix of functions that characterized it before the destruction and still does, and that is so vital to maintaining the quality of the urban environment. The premise of thinking the reunified city gave the most utopian and progressive features to most of the projects. Reinforcing this, the area in question, covering $10 \mathrm{~km}^{2}$, was limited between the Tiergarten to the west, Alexanderplatz and Museum Island to the east, the river Spree to the north, and the Mehringplatz to the south. It was divided between the two Germanys, since it was located 2/3 in Soviet territory and 1/3 in Allied one. In addition, the area gives rise to important architectural objects, such as the Brandenburg Gate, Museum Island, Humboldt Universität and the Reichstag, seat of the German Parliament, which was in ruins at the time (Image 1). 


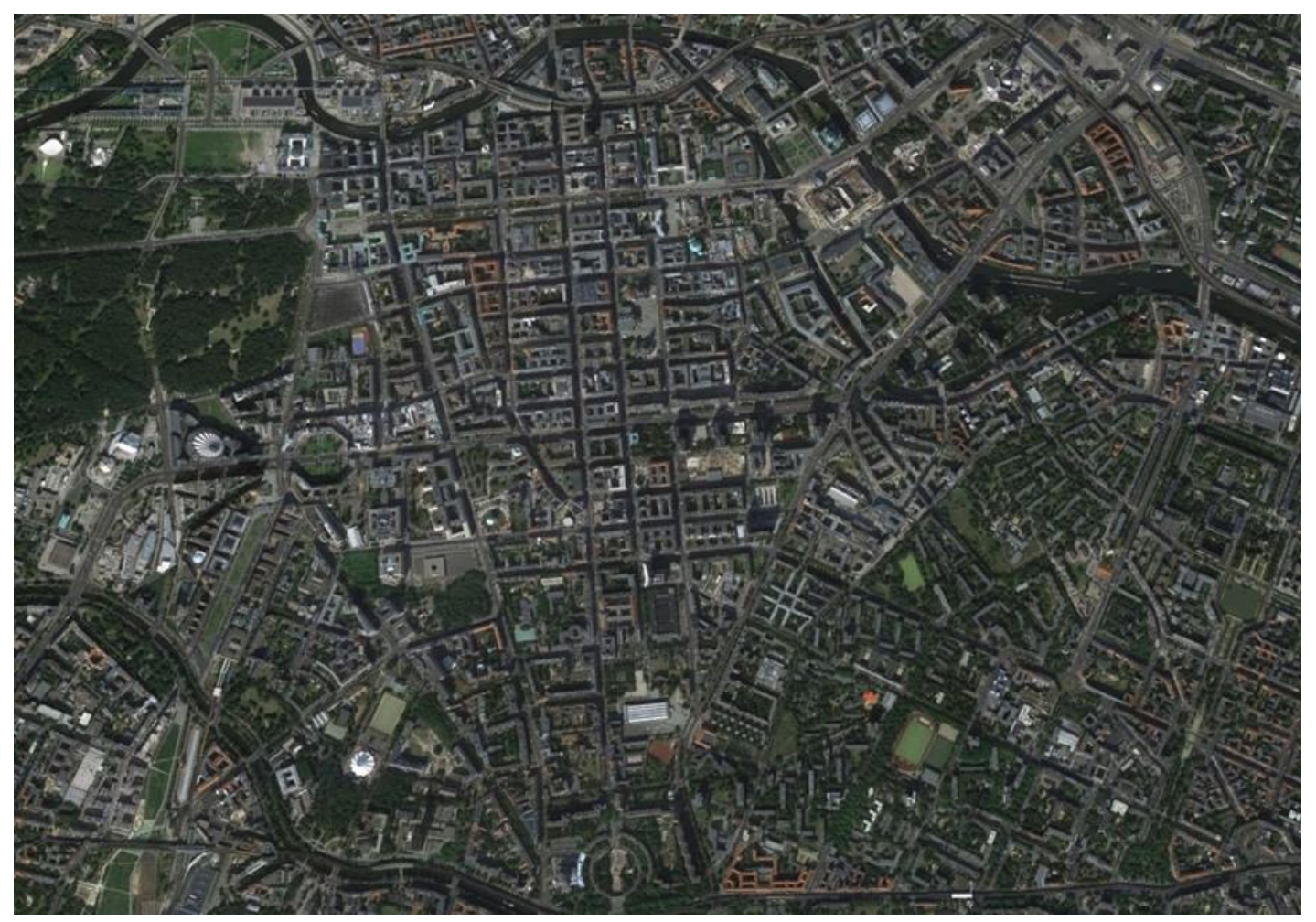

1. Competition area. Source: Google Earth.

The jury included prestigious names like Alvar Aalto, Cornelis van Eesteren and Pierre Vago. Walter Gropius was initially part of the jury and that was one of the reasons that convinced Le Cobusier to accept the invitation to participate in the contest. But for health reasons Gropius was prevented from continuing the function. The competition received 86 proposals from various cities beyond Berlin, such as London, Vienna, Paris and Florence. Of these 86, 13 were eliminated, including Le Corbsuier. Among the proposals submitted, a few stood out, in addition to Le Corbusier`s: Spengelin, Eggelin \& Pempelfort, contest winners; Hans Scharoun, second place; Alison and Peter Smithson together with Peter Sigmond, third place; Jorn Utzon; Sven Markelius; Luigi Piccinato; among others. Soviet architects also sent works to the contest but they could not develop their projects, since their professional association banned its members from participating. While most of the proposals are linked in some way to the principles of CIAM, and the proposals of Hans Scharoun and Alison and Peter Smithson (Images 2 and 3) represented alternative schemes based on new concepts, linked to the agenda of the new generation, the project proposed by Le Corbusier arises along the way, closely linked to the canonical principles of modern urbanism, but also sensitive to some of the concerns that have characterized the debate caught over the 1950s.

Also, it is important to keep in mind that Berlin was, throughout the twentieth century, the subject of proposals and contests that thought solutions to the city, many of them having been only kept on paper, as fragments of utopia. However, the 1958 contest, though also not built, differs from other proposals to Berlin since it would transform the center of Germany`s capital in a planned area, something that was unusual including European level. This condition was made possible by the state of destruction provoked by the bombings of WWII. Thus, Corbusier had the opportunity to work with problems similar to those studied by him to the center of Paris more than thirty years before, without needing to have premised on the destruction of the city center. 


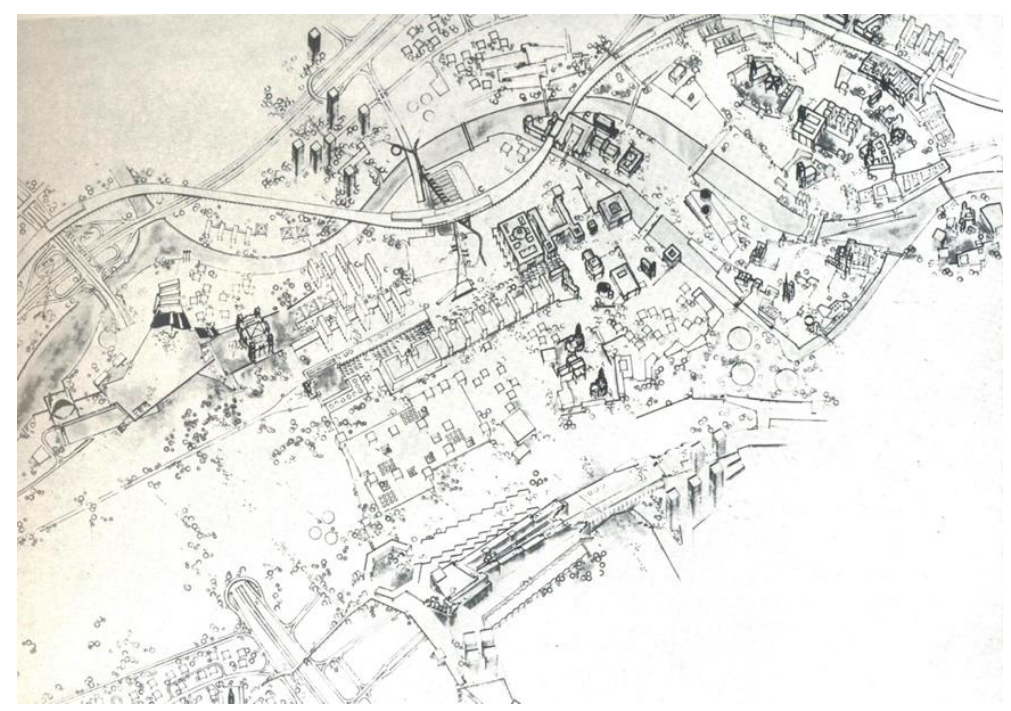

2. Proposal submited by Hans Scharoun for Berlin. Source: Geist, Johann Friedrich; Kürvers, Klaus; Rausch, Dieter: Hans Scharoun. Chronik zu Leben und Werk. Berlin: Akademie der Künste, 1993, pp. 115.

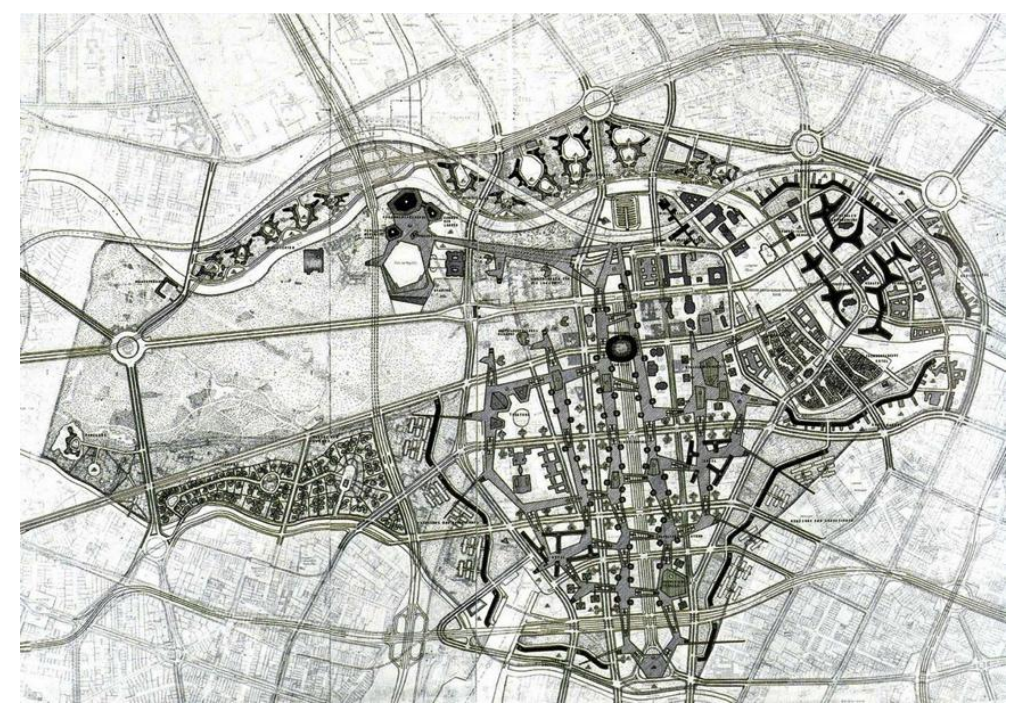

3. Proposal submited by Alison and Peter Smithson for Berlin. Source: Bosman, Jos and others: Team 10 1953-81. In Search of a Utopia of the Present. Rotterdam: NAi Publishers, 2006, pp. 76.

Le Corbusier`s proposal was thought by him more as a scheme of ideas or a master plan, than a widely developed project. Thus, the present analysis was limited to the level of development achieved by the project that was handed out, and was based on a not very wide graphic material found in "Le Corbusier et son atelier rue de Sevres 35 - Oeuvre complete 1957-1965" as well as at the Fondation Le Corbusier site ${ }^{12}$.

Le Corbusier developed the project in his office at Rue de Sevres in Paris; however, as he had lived in Berlin for about a year, he had acquired relative intimacy with the city and its center. Even though he did not went to Berlin at the time of the preparation for the contest, he had a deep knowledge about the peculiarities and characteristics of the area. As his design strategy for the configuration of the area and for the recovery of pre-existing historical center, he used well-outlined urban infrastructure networks as a key element for generating new public spaces. In addition, he incorporates in its proposal some new ideas regarding the treatment of public spaces and their

\footnotetext{
${ }^{12}$ www.fondationlecorbusier.fr
} 
relationship with the existing urban fabric, combining urban elements and equipment of different scales, and thus, creating transitional zones.

Le Corbusier`s premise for the project was to preserve the remaining historic buildings and insert the urban fabric as a sort of overlay, while keeping a continuity with key pathways and structuring lines of the existing track. This stance on existing tissue differs so much from that adopted by Hans Scharoun, as that taken by Alison and Peter Smithson, respectively second and third place, and are, along with Le Corbusier project, among the most published and cited in books and magazines that discuss the contest. While Scharoun completely eliminates the existing urban layout, considering that the original fabric and its road standard lost all meaning they had previously, Smithson propose to interconnect two road systems based on opposing geometries - one at ground level and corresponding to remaining original fabric of the city, and the other superimposed on this, composed of raised platforms by setting a non-orthogonal grid. Thus, one can say that with respect to how to intervene in the existing city, or what remained of it, Le Corbusier project stands midway between Scharoun`s project and Smithson`s, as it keeps in part the existing fabric, and inserts a new urban and road structure at strategic points, but in most cases considering the existing structure and seeking to link with it.

Following the principles of project advocated by CIAM and its most universalizing aspects, Le Corbusier establishes a functional zoning of the area, focusing on the distribution of governmental, administrative, cultural and economic activities. Thus, as shown in Images 4 and 5, it deploys the cultural sector surrounding the Unter den Linden; the economic sector, with shops, offices and services are placed in the southern portion between Unter den Linden and Mehringplatz; adjacent ministries to the Reichstag, the seat of Parliament; diplomatic representations are in the area south of Tiergarten; and the sector for the municipal administrative activities are to the east, near Alexanderplatz. That is, different from common sense about modern urbanism, Le Corbusier implements the activities required by the program considering the characteristic uses of each part of the area and respecting, thereby, the bond of the new proposal with the tradition of the place. The area surrounding the Unter den Linden already covered, before destruction, a number of cultural facilities, as well as the area near the Reichstag also was characterized by government activities, the area south of the Tiergarten had tradition in hosting diplomatic activities, and the area near Alexanderplatz already had activities related to the city.

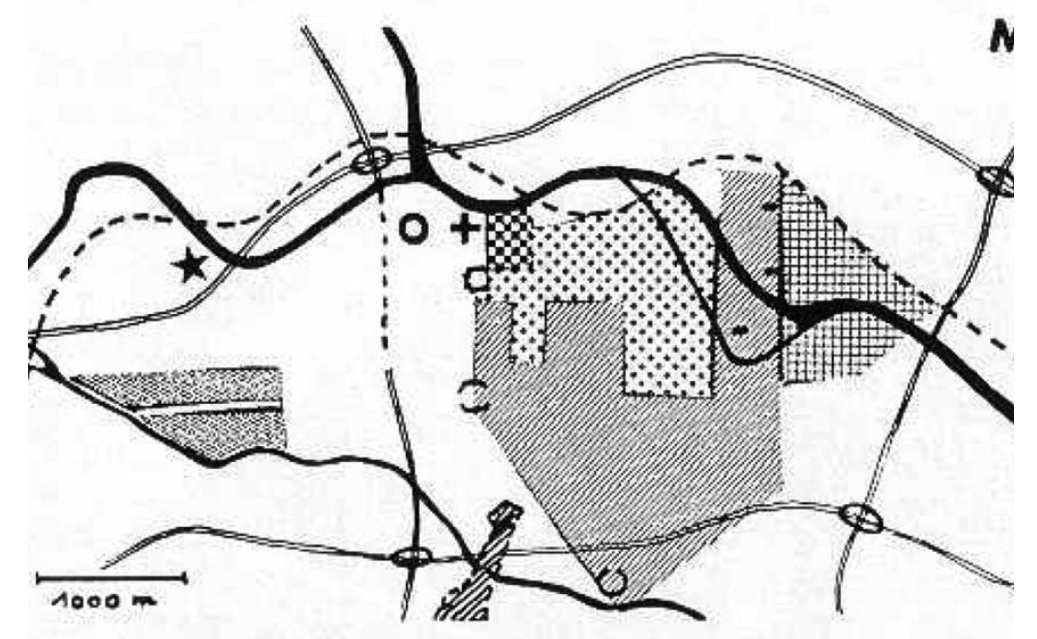

4. Sketch of the functional zoning estabilished by Le Corbusier for Berlin. Source: Boesiger, Willy; Corbusier, Le: Le Corbusier et son atelier rue de Sevres 35: Oeuvre complete 1957-1965. Zurich: Editions d`Architecture, 1966, pp. 230. 


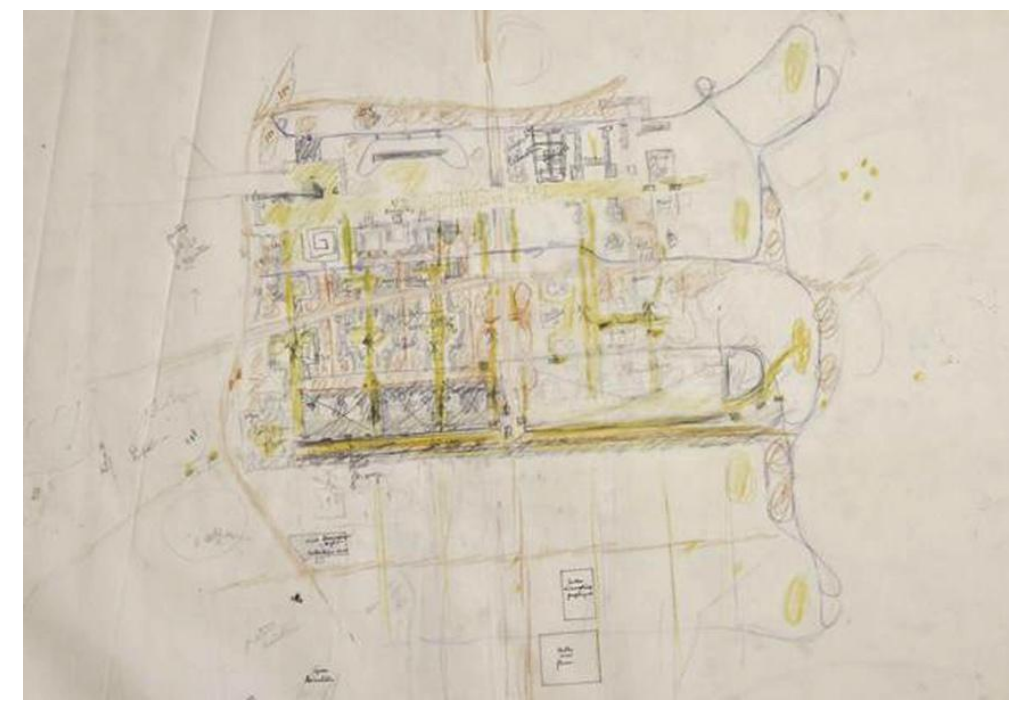

5. Inicial sketch of the plan developed by Le Corbusier for Berlin. Source: www.fondationlecorbusier.fr (Urbanisme, Berlin @FLC-ADAGP 4/7)

In addition, he proposes changes in some of the important urban facilities of the area, as the transformation of Friedrichstrasse station in Hauptbahnhof (Central Station); the implementation of a large roundabout in place of the Hackescher Markt; and placing a series of skyscrapers with plant in a kind of irregular " $\mathrm{T}$ " format at strategic points of the plan, concentrated mainly on the east bank area. But among the boldest changes is the proposal to transform Unter den Linden into a pedestrian promenade, increasing the use and enjoyment of the cultural facilities of the area. The car circulation is solved with elevated highways crossing Unter den Linden at specific points related to the main existing roads in the plan, and parking areas are situated in narrow bands in front of buildings. With this gesture, Corbusier intended to rescue the identity and the features that the avenue had in the past, before the appearance of vehicles, when it was an avenue aimed at pedestrians. Furthermore, it also aimed at establishing Unter den Linden as a liaison between the different functions that develop around it and at the same time embrace it as scale transitional element - solutions that present answers to a series of issues debated in recent congresses of CIAM in which he participated. However, this solution displeased the jury, which decreed that Unter den Linden should be used for car traffic.

In the area between south of Unter den Linden and Mehringplatz, the solution adopted by Le Corbusier refers to some extent to the discussions and experiments carried out by the new generation in the congresses of the postwar CIAM with respect to issues related to the urban block configuration. These issues were addressed in architectural design and theoretical framework mainly by members of Opbouw group, the Dutch arm of CIAM led by Bakema, from the approach to the scheme consisting of formations of housing units (or stamps), which grouped form neighborhood units. The housing units were formed by combining groups of different types of housing, so that a significant social and variety of types and sizes of families could live integrally also in diverse areas. When grouping and combined housing units form the neighborhood units, larger units, endowed with shops, schools and recreational areas, which, separated by wooded tracks, play the role of defining the scale of the neighborhood. Thus, the housing unit, to act as recognizable unit of architectural and social composition, which refers to the open block idea, was the originator scheme found by Opbouw to organize the space and at the same time expressing the differences in society and individuals found in a series of housing projects presented by them in successive congresses of CIAM, as Pendrecht (1948-1953), or Alexanderpolder (1953-1956), both in Rotterdam. 
In the area located south of Unter den Linden, even not it is not a program for dwelling, Le Corbusier adopts a similar ordering scheme. He projects open blocks from mirroring two linear buildings in a kind of "C" shape, creating thereby a compositional unit in each block, which is repeated in the plan. Despite the program differences, these units designed by Le Corbusier have parallels in compositional terms and space configuration with Bakema`s housing units, and when grouped they can also refer to the idea of neighborhood units. Moreover, with this configuration, Le Corbusier reaches, within each block, a greater variety of built-up areas and open spaces. Also the character of these areas achieve some diversification, since the inside of each block becomes a semi-public space - and not a private one - with different gradations at every point, and become usable for purposes such as leisure, entertainment and exchange between users. These solutions are in accordance with the idea of achieving greater differentiation and thereby individuality in different parts of the project. This unit, with a repeatable pattern, is evenly distributed in the plane, creating a structure that shows up homogenous but contains internally variety and differentiation. The Images 6, 7 and 8 show the final plan.

However, Le Corbusier`s project was among the 13 eliminated by the jury. According to the report issued by the jury, the project solved fully and satisfactorily circulation problems common to large cities, such as Berlin, but Corbusier's decision to deploy one of his skyscrapers between Unter den Linden and the river Spree, hiding a municipal administrative building located on the other side of the river, also angered the jury, which eventually disqualify the project. Nevertheless, this seems like a minor problem, since even without having obtained classification, without having reached a higher stage of development, and without having been built (which joins it to the huge number of projects proposed for Berlin that never got off the ground), the design of Le Corbusier fulfilled the role of proposing a solution that, while linked to some of the canonical principles of modern architecture, also shows sensitive to those raised by the new generation in discussions carried out in the period. Thus, at an already mature point of his career - just seven years before his disappearance - he shows awareness to the theoretical debates of the period as opposed to the common sense regarding his place on modern urbanism.

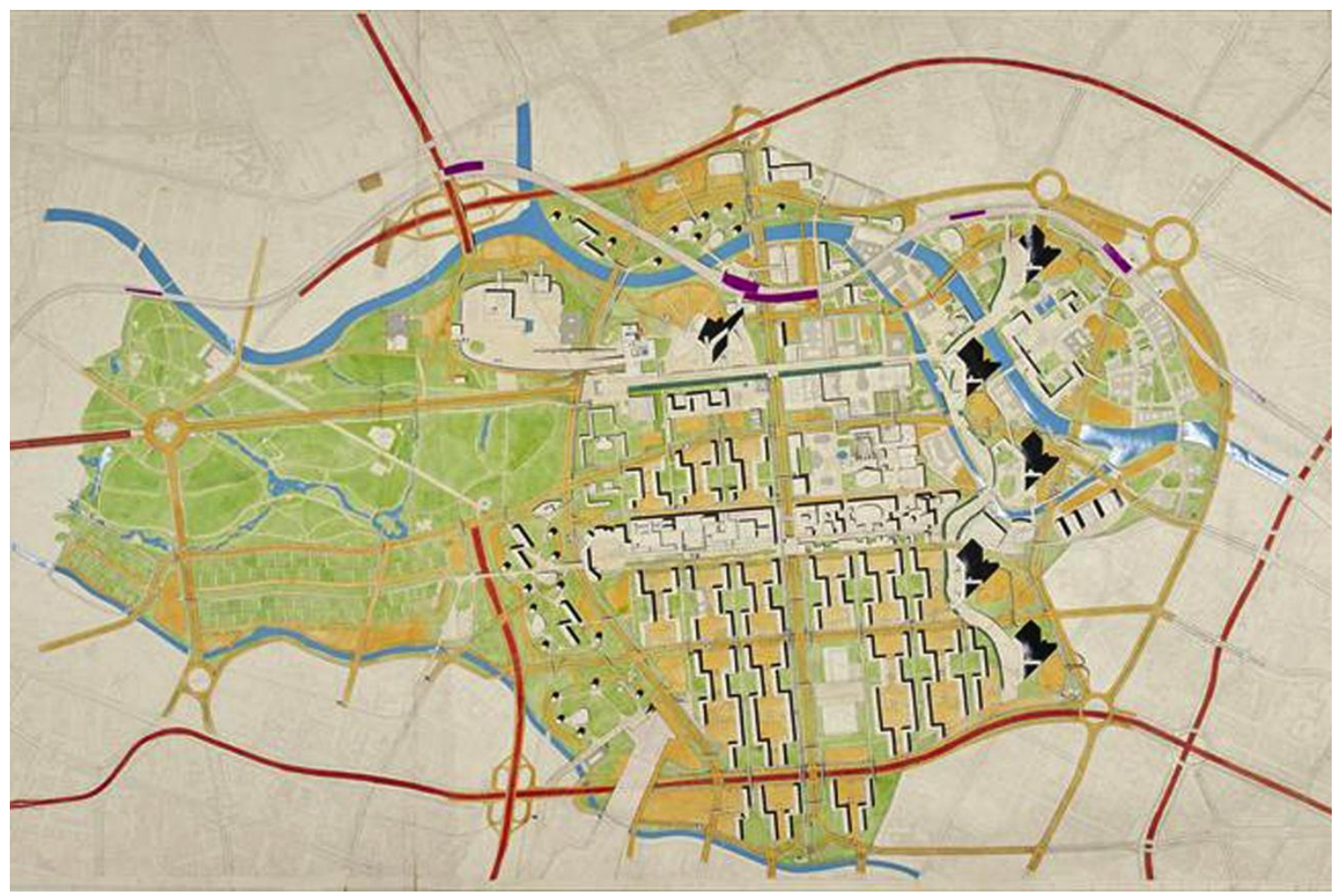

6. Proposal submited by Corbusier for Berlin. Source: www.fondationlecorbusier.fr (Urbanisme, Berlin @ FLC-ADAGP 1/7) 


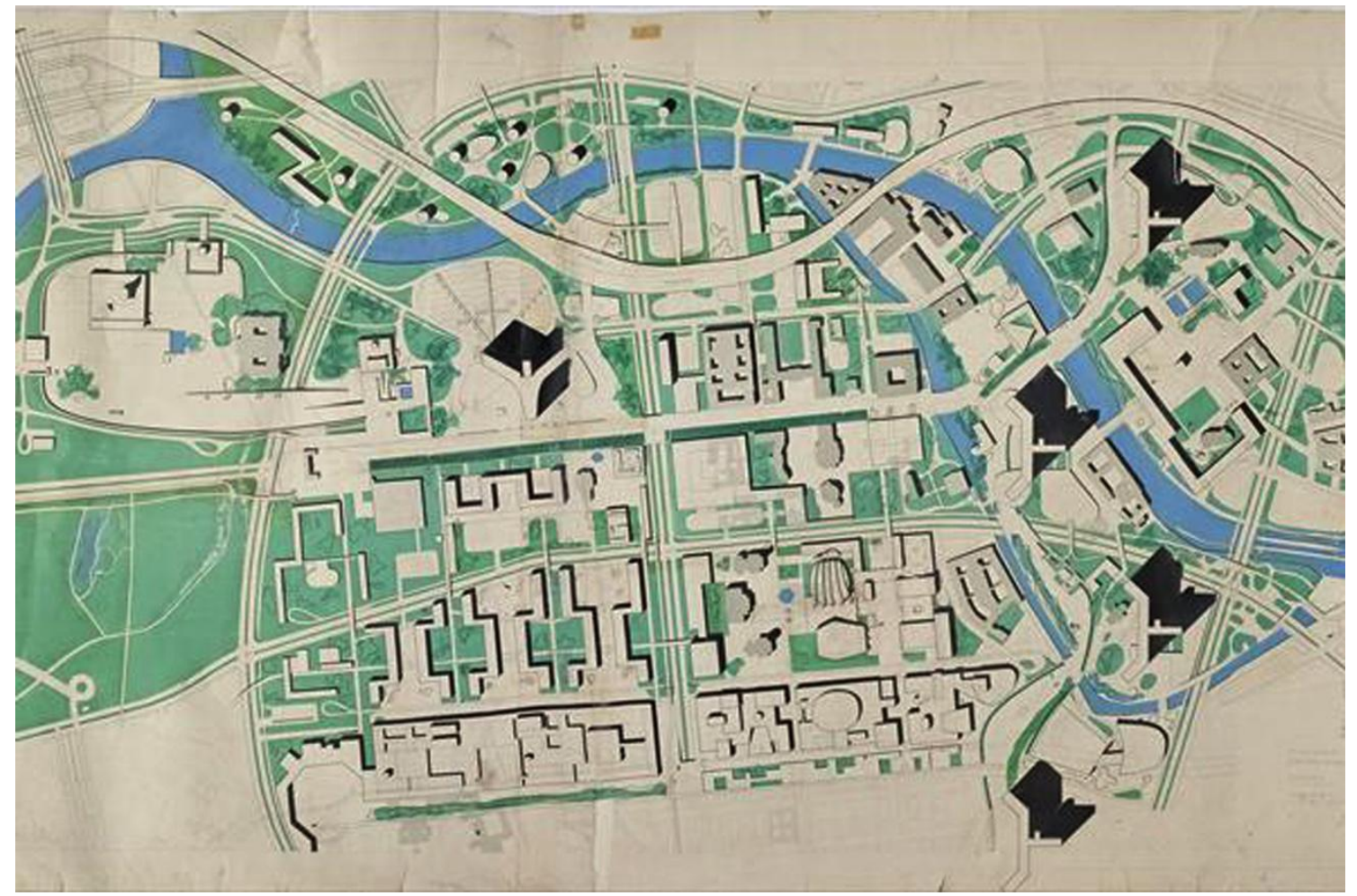

7. Plan of Le Corbusier for Berlin, signalizing in green the green areas. Source: www.fondationlecorbusier.fr (Urbanisme, Berlin@FLC-ADAGP 6/7)

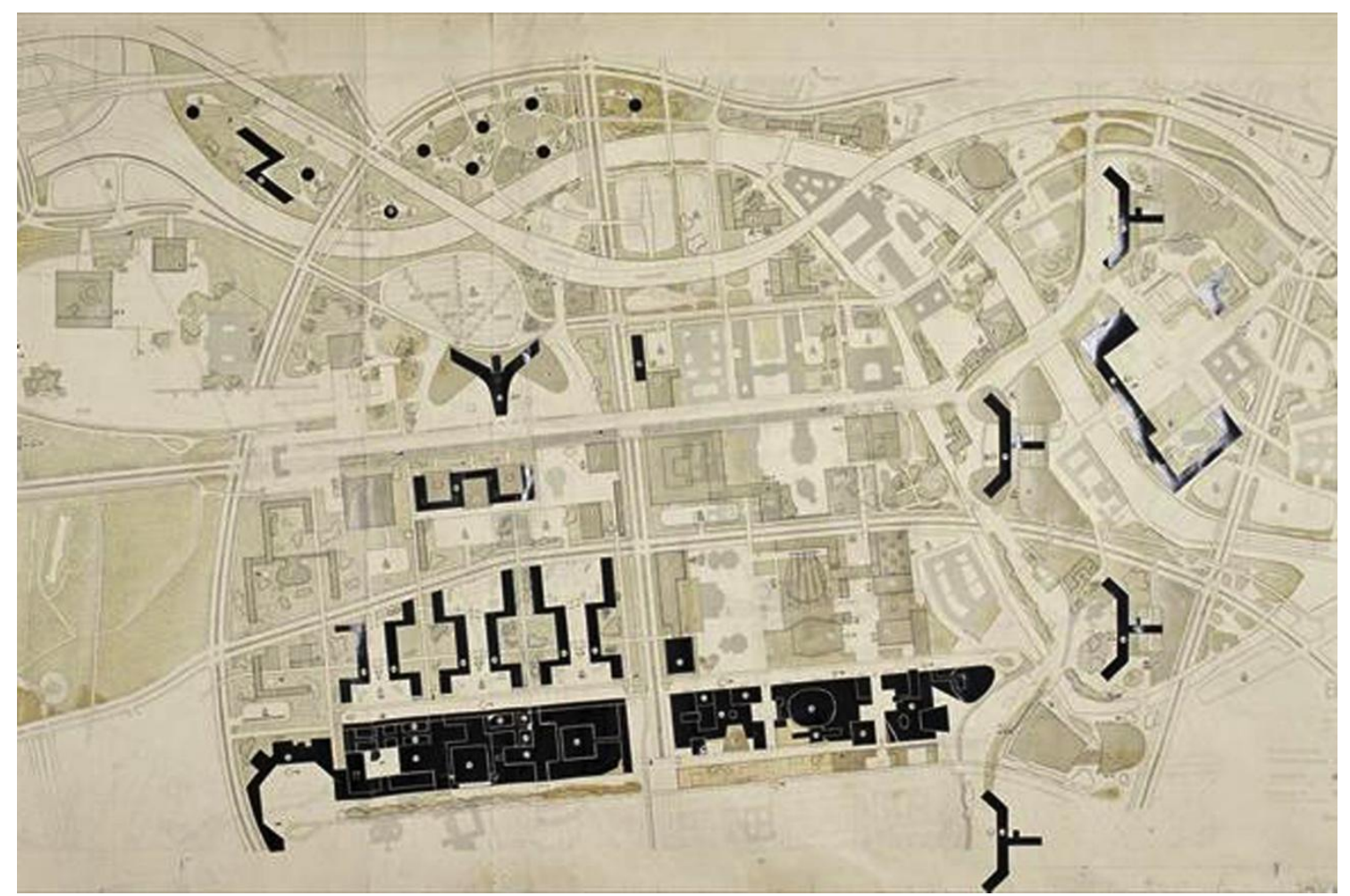

8. Plan of Le Corbusier for Berlin, signalizing in black new buildings. Source: www.fondationlecorbusier.fr (Urbanisme, Berlin @FLC-ADAGP 7/7) 


\section{Conclusions}

More than thirty years after the completion of Plan Voisin, at which Le Corbusier presents its proposal for the center of Paris, he has the opportunity to develop his ideas about architecture, urban planning and modern society to the center of Berlin. Although both represent very optimistic expressions of his time and both being marked by a deep belief in technology and the future of humanity, the project to Berlin differs from the Plan Voisin in that, when touched by the questions posed by new generation of modern architects throughout the transitional period located in the 1950s, he anticipates a number of issues that would be on the agenda of architecture and urbanism in the 1960s. By placing the ideas of universality and individuality acting jointly, Le Corbusier turns out contrary to the common sense and the main narratives dealing with the architectural production of this period, which put both ideas as conflicting ones; similarly, it also defies common sense on his own production in urbanism, whose criticism usually is linked with matters arising out of the canonical principles - and to some extent utopian - adopted on the project to Paris.

On his Berlin project, Le Corbusier adopts, on the one hand, a number of design strategies more linked to CIAM`s booklet and the Athens Charter, such as huge loose towers amid large open areas, and the functional zoning, escaping from the already well established idea of the need for mix of functions. But on the other, he takes others that corroborate the view that his project shows sensitivity to issues addressed in the period in which it was developed. Among them we can mention: an adjustment of scale (especially when compared to Plan Voisin project), connecting with the city scale and limiting the insertion of larger objects to specific points of the plan; the insertion of transitional elements, either of scale, either of function, a strategy that relates to the idea of human association as defended by Smithson in the Statement on Habitat as a basic principle of organization and design tool; the inclusion of a significant typological and space varieties, both for the built spaces and the open ones; concerns about linking his plan with the existing plot, albeit partially; and the adoption of a system for urban blocks configuration that refers to the idea of housing units combinations that generate neighborhood units, a subject widely discussed in CIAMs by the new generation. That is, as seen on Image 9, different than the main narratives usually place, Corbusier did not consider the problem of universal and individual issues as mutually exclusive, but rather devoted himself to the task of putting these two ideas working and dialoguing with one another, explaining, with this, the nuances and complexities of the modern city of the 1950s.

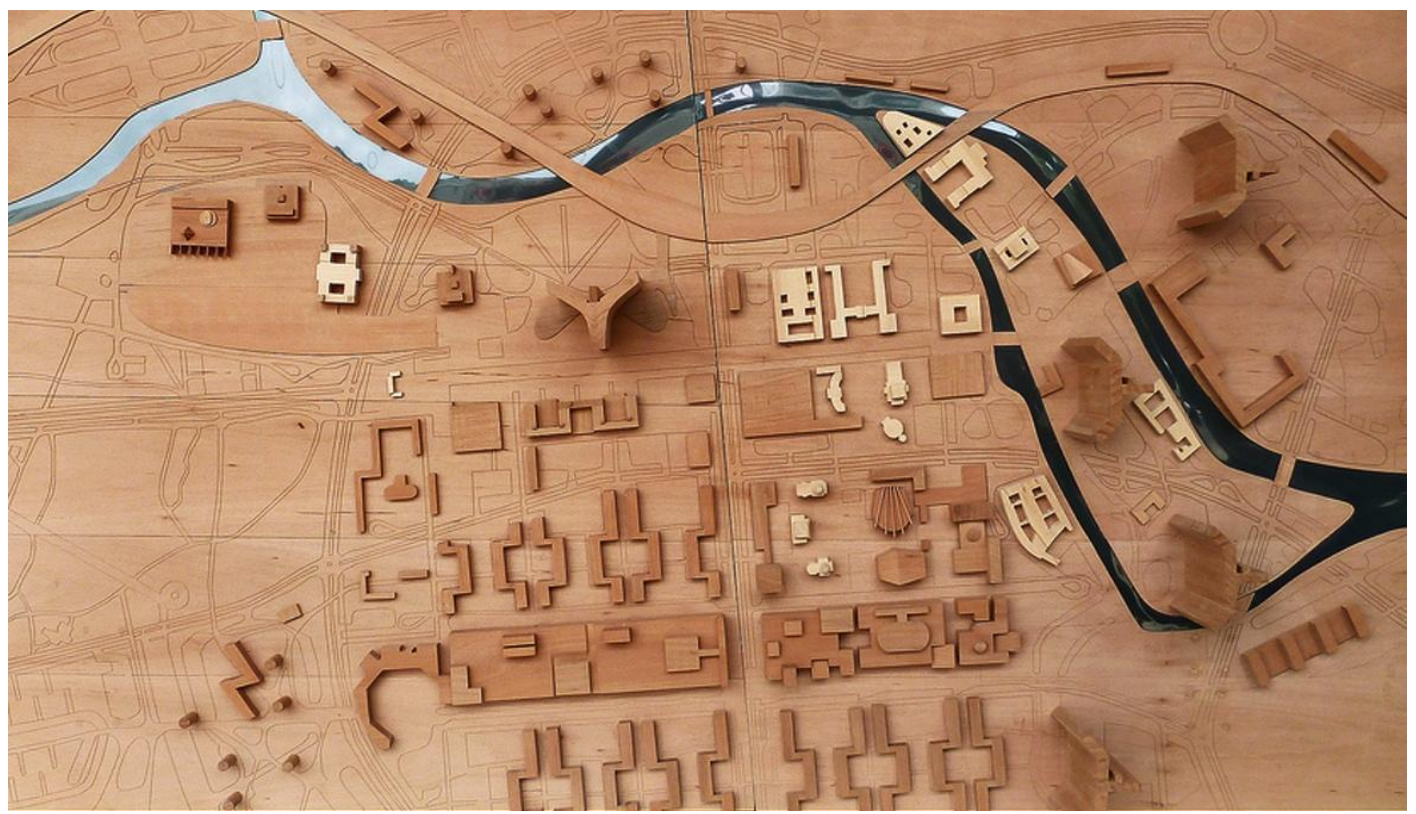

9. Model of the plan submited by Le Corbusier for Berlin. Source: www.flickr.com. 


\section{Bibliography/ references}

Boesiger, Willy; Corbusier, Le: Le Corbusier et son atelier rue de Sevres 35: Oeuvre complete 1957-1965. Zurich: Editions d`Architecture, 1966

Cohen, Jean-Louis: Le Corbusier: An Atlas of Modern Landscapes. New York: Thames \& Hudson, 2013

Montaner, Josep Maria: Depois do Movimento Moderno. Arquitetura da segunda metade do século XX. Barcelona: Gustavo Gili, 2001

Mumford, Eric: The CIAM discourse on urbanism, 1928-1960. Cambridge, Massachussets: MIT Press, 2002

Pedret, Annie: Representing history or describing historical reality?: the universal and the individual in the 1950. Conference: Universal vs. Individual: The Architecture of the 1960. Chicago: Illinois Institute of Technology, 2002

Smithson, Alison. The Emergence of Team 10 out of CIAM: Documents. London: AA, 1982

Smithson, Peter and others: Doorn Manifest. CIAM meeting on 29, 30 and 31 January, 1954. In: Smithson, Alison: Team 10 Primer. Boston: MIT Press, 1968

www.fondationlecorbusier.fr 